\title{
Improving Digital Library Experiences and Support with Online Research Guides
}

\author{
Laura Brewer, Holly Rick and Karen A. Grondin \\ University of Phoenix
}

\begin{abstract}
With a goal of improving the development and delivery of effective online information literacy resources, the purpose of this study was to look at how program level and the timing of the introduction of a Literature Review library guide within the program influenced online business student perceived value of the resource. A population of undergraduate business students $(\mathrm{N}=355)$ and online MBA students $(\mathrm{N}=319)$ were introduced to a Literature Review library guide during specific points in their programs. Students were asked to complete an online survey that included 17 closed-ended items designed to measure perceived usefulness, satisfaction and likeliness to use the guide again. The survey also included two open-ended questions asking students to discuss those elements of the guide they found most valuable and whether they wanted any additional features included in the guide. The data collection strategy required faculty post information about the Literature Review library guide and the survey in their courses at two specified times in the course. A low response rate (3.5\%) may have resulted from inconsistencies in how faculty shared information about the guide and the study in their courses. Although the small sample size $(n=24)$ limited the planned analysis, and results indicated no statistical significance between groups, descriptive findings were reported, and trends were used to revise the resource and inform future development of library research guides. Overall, students reported being satisfied with the resource and found it usable. Graduate students were more likely to report elements of the guide that supported effective search and evaluation strategies were valuable; whereas, undergraduate students tended to value the links to writing resources. Student feedback also suggested that the earlier the guide was introduced in the program, the more likely students would use the resource. Adopting a model that embeds resource guides early in academic programs and aligns guide content with the curriculum should lead to increased use of the resource.
\end{abstract}

Keywords: Digital library services, student perceptions, distance learning, LibGuides, business students

Brewer, L., Rick, H. \& Grondin, K.A. (2017). Improving digital library experiences and support with online research guides. Online Learning, 21(3), 135-150. doi:

10.24059/olj.v21i3.1237

\section{Introduction}

The traditional role of a library has been to provide crucial resources and services for student needs beyond providing books and serials. While web-based content and electronic media are available at students' fingertips, the web-based content may not provide the support that students need to complete their programs. Students struggle to find scholarly resources to support their academic work. For online students, these struggles can become overwhelming. Many students fall into search habits that may assist them in completing an assignment, but will not build 
lifelong learning skills or information literacy skills needed for future employment. Digital libraries play an important role for students; librarians are educators that procure content and provide instruction on how to use and evaluate resources.

University libraries have been slowly building robust digital collections to support their students. Digital library collections can be difficult to navigate, and many are developed on an infrastructure that is not intuitive to those conducting research. Cothran (2011) strongly argues for "librarians to focus on improving the usability and accessibility of library resources by linking library databases and Google Scholar, instead of simply discouraging students' Google Scholar usage" (p. 298). Without some intervention with a library-trained professional, students may find obstacles accessing library content.

Not all libraries offer for credit courses or provide embedded librarians to support the curriculum. Academic libraries have been exploring new ways to include library instruction that engages students during their times of need. By building course materials that support the learning process and providing information literacy instruction in the learning management system (LMS), students should have a better experience using the library resources, be more likely to find the appropriate library content, and build information literacy skills necessary for lifelong learning. Librarians will be better able to strategically build content that supports the online learner if they understand students' perceptions of the resources.

Buehler (2004), Shank and Dewald (2003), and Bowen (2012) have identified value in embedding library content in the LMS system, which brings the library to the students and faculty where they "work." Improving the library's connection with other university systems, like the LMS, can result in an increased return on investment in the library collection. The work completed by Buehler (2004), Shank and Dewald (2003), and Bowen (2012) did not did not examine students' perceptions of the library content or the role of timing when students will get access to library instruction and content.

If librarians are not able to be in the classroom to teach information literacy skills, students will likely resort to their previous information seeking skills, which may not lead to locating the most appropriate resources to support their work. Information literacy support and materials must be embedded within the curriculum to support student learning and to be recognized and prioritized in academic plans. As noted by Khan and Qutab (2016) "The librarians must understand that users always know their information needs, but they do not know where to find these information" (p. 312).

Librarians are required to create materials that students find supportive, useful, and that students will value for their research tasks. When students cannot locate or access the material they need, they can become disenfranchised. Factors that impact how students perceive online materials include slow downloads, difficulty reading online due to other technology options such as games, a distraction from social media, and emails. Students tend to use specific journals because of familiarity. By understanding how online students make meaning about their experiences with the library and the library's resources, librarians and academic affairs personnel can better promote online student learning.

If students do not believe that a resource is valuable, they will not use that resource. Wu and Chen (2012) found graduate students often use library resources and that graduate students recognize library resources are important for their classwork. Students can be confused about how to find information and what resources may be needed to complete their work; the library provides 
students with more than subscription databases, books, and serials. Resources that explore topics, present information literacy in a new way, or support an assignment can be perceived as valuable to students in their research process.

Early work by Beagle (2000) identified that librarians need to take an active role in the instructional design of information literacy teaching and resource creation. Additional works by Gilbert, Knutson, and Gilbert (2012), Ouellette (2011), and Liu and Luo (2011) indicated student perceptions of the library resources impacts student learning, collection development, and suggested patterns related to how students engage and perceive resources. One of the ways the library takes an active role is to assess the unique needs of their student body.

This study was conducted at a large institution with a diverse, primarily online population. According to the National Center for Education Statistics (2015), as of Fall 2015, 165,743 students were enrolled; 133,211 were undergraduate students and 32,532 were graduate students. Ninetyfive percent of graduate and ninety-eight percent of undergraduate students were enrolled solely in distance education. The University has eleven colleges and schools. The Business programs graduate more students than any other University program with 4,393 graduating with a Bachelor's in Business Administration and Management and 2,772 graduating with an MBA in 2015. The Business programs were selected for this study because they represent the largest group of students and thus the resources had the potential to have to benefit the greatest number of students while under study. Each ground campus at the University has a Student Resource Center that provides assistance with writing and mathematics, while University Library does not have a ground presence and is entirely virtual. The University resources used in this study, including the writing resources, were all completely online resources.

This study was designed to obtain a descriptive evaluation of online students' experiences with a University library resource designed to support their research activities. Researchers created a survey to capture students' perceived usefulness, satisfaction and likeliness to use the library resource provided in their course. Data was collected without student identifiers to promote honest feedback. The remainder of this paper will include a brief literature review, the research questions guiding the study, as well as the method of data collection and results. Implications for further research will be discussed.

\section{Literature Review}

Murray (2015), Catalano (2016), and Haddow (2012) have shown that having a librarian work with students increases retention and increases the information literacy benchmark for the University. When moving curriculum to an online platform regardless of the learning management system (LMS), the ability to integrate a librarian in the classroom experience can become almost impossible. "Research in virtual reference environments reveals that leading factors for non-use include unawareness of the service, satisfaction with other information sources, and lack of confidence in the chat librarian's ability" (Liu \& Luo, 2011, p. 231). While librarians and faculty build many different types of instructional materials and resources to support their students, they may not look at how the resource is being used, where the resource is placed within the course or program, or care about how often students use the resource.

Historically, librarians have developed and made available library guides and pathfinders as a service to library patrons and to support information literacy instruction. While library guides 
can take the form of paper handouts or electronic tools, it is important to understand what library guide characteristics students perceive as valuable to their academic experiences and success. Students from a variety of backgrounds come to the University with diverse experiences that may influence their library research skills. Librarians build guides without having information about students' previous experience in using the library or baseline of their information literacy skills. Librarians also aim to design the guides to support multiple learning styles. Bellard (2007) identified that while the majority of graduate students self-reported their library skills as fair or better, many could not tell the differences between a library catalog and a database and were also unable to identify subject specific databases. Bellard's study offered the participants an optional library workshop, and the students who attended the workshop reported a higher comfort level with library resources and a majority of the student participants felt that library instruction should be part of the curriculum.

Green and Browser (2002) found that a collaborative teaching environment including a faculty librarian helped reduce graduate student anxiety. Students felt that the faculty and the librarian each had unique areas of expertise that were helpful as they went through the dissertation process. Both Rempel (2010) and Green and Browser (2002) found that students benefit from librarian involvement, especially when working on the literature review.

\section{Using Guides}

Research around the utilization of library guides has identified that when library guides are used, these guides do improve research skills, GPA and retention (May \& Leighton, 2013; Wakeham, Roberts, Shelley, \& Wells, 2012). However, most utilization studies have focused on how the library guides are built and embedded (May \& Leighton, 2013; Wakeham, Roberts, Shelley, \& Wells, 2012), and not on how student perception of the guide may relate to student decisions to use the resources. Previous research also has not examined how student perceptions might be influenced by when an online library resource is introduced within a course or program.

\section{Timing}

An important piece of planning for library research skills instruction is the timing of the instruction. Many studies have looked at the benefits of offering instruction at the student's' point of need. Rempel (2010) conducted a longitudinal study of graduate students who attended a literature review workshop presented by the library. The workshop was offered to students when they were new to their program, and the students found the workshop was an effective use of time. It is also important to consider programmatic requirements when determining the point of need. For example, Rempel (2010) and Neves and Dooley (2011) point out those students who are required to submit a project proposal benefit from library instruction at an earlier time than those who do not have this requirement. Additionally, students who had to come up with a topic tended to start their literature review almost a full year after starting their graduate research. Those students would probably benefit from library instruction at a later time. Mahaffey (2012) concluded that students valued having a research guide when they needed the resource.

Liu and Luo (2011) focused on how often graduate and undergraduate students used their digital library. Their research showed that graduate students requested earlier access to the online library and content to ensure that they were current in the field. The undergraduate students in this study noted that the library was difficult to use and the material was older. This discrepancy in experiences based on student level may be explained by under-developed research skills of undergraduate students or a lack of complexity in their research needs. 


\section{Perception}

Most of the perception research on online library guides revolves around the perceptions between print versus electronic resources (Liu, 2006, Lombardo \& Miree 2003). Other perception research has been completed on the adequacy of the library resources for both ground and online (Spahr, 2015). Student and faculty perception data can be helpful in assessing library instruction, materials or to re-evaluate services. However, additional information about student satisfaction with the timing of the introduction of the library resources may also support informed decisions about information literacy instruction in the online environment.

\section{Theory}

A social constructivist framework suggests learning is constructed through social interactions (Vygotsky, 1978). For this study, online students interact with the information literacy resource, a library guide about literature reviews, and students make meaning of these interactions. The meanings that online students attribute to their experiences interacting with the literature review library guide will likely influence their future interactions with the University Library. If we better understand online student experiences with the University Library, and with this particular online library resource, we may be better able to support the development of effective online information literacy resources.

\section{Research Questions and Hypotheses}

This study was directed by two research questions, and each question was associated with a hypothesis.

- RQ1: How does program level influence online students' perceived value of a "Literature Review" online library guide?

- H1: There will be no significant difference between undergraduate business and MBA students' perceptions of the value the "Literature Review" online library guide.

- RQ2: How does the timing in which the "Literature Review" online library guide is introduced to students influence their perceived value of the resource?

- H2: The earlier the "Literature Review" online library guide is introduced to students, the greater the students will value the resource.

\section{Population and Sample}

\section{Method}

The population for this study is online undergraduate business students and online MBA students. Online undergraduate students were solicited from one research course introduced early in the program $(\mathrm{N}=83)$ and from the program's capstone course $(\mathrm{N}=561)$. The MBA sample was recruited from a research course introduced early in the program $(\mathrm{N}=232)$ and from the program's capstone course $(\mathrm{N}=314)$. The purposive sample consisted of all students enrolled in all sections of these four courses $(\mathrm{N}=1190)$ with start dates during September and October 2016. Enrollment numbers were calculated by those students who were included on the final class rosters after the School's drop/add dates for these courses.

\section{Method of Data Collection}

Data was collected using online surveys made available to students with the Literature Review library guide within the four business courses. The online survey included 17 closed- 
ended items that had been used by the University Library to assess usability and design for other projects. These items were revised slightly to measure student experiences with the Literature Review library guide. The 17 items were designed to measure perceived usefulness, satisfaction and likeliness to use again using 5-point Likert scales where the higher the value indicated the greater the usefulness, satisfaction, and likeliness to use again. Also, two open-ended questions were asked of all students:

- What element of the Literature Review library guide do you think was most valuable and why?

- Is there anything you'd like to see included in Literature Review library guide that was not currently part of the resource?

All faculty teaching these four courses with start dates between September 13 and October 18, 2016, were sent an email before their section start date informing them about the Literature Review library guide and study. The faculty had not seen the resource before this initial email. The email was sent from the School of Business leadership and asked the teaching faculty to create two announcements in their online course sites. A template for both announcements was provided. The announcement explained that the University Library was piloting the new online library resource in this particular course and the resources were designed by the University Library to support students with the development of a literature review. The announcement went on to explain that the resource was an optional supplement to the course and that interested students who chose to use the resource would also be asked to voluntarily complete a short survey to provide feedback about their experience using the resource. The announcement also included a link to the short 5 to 10-minute online survey. The online business courses are five weeks in length and faculty were asked to post two announcements about the guide and the survey in their classes during week 2 and week 5.

The study was designed to manage concerns about human research subjects. Participation was voluntary and a standard informed consent document was included before students gaining access to the online survey. In addition to using anonymous survey URLs, researchers asked to waive documentation of informed consent as a mechanism to maintain the anonymity of all student participants.

\section{Limitations with Response}

A few issues impacted student response patterns. The researchers developed the text for the faculty course announcements about the Literature Review library guide and the associated student survey, as well as instructions for faculty with regards to how and when to share the information with their classes. However, the researchers had to rely on department administrators to share this information with faculty and for faculty to post the announcements in their classes on schedule. A review of class websites indicated many of the faculty did not post one or both of the announcements (Table 1).

While there were 1190 students enrolled in these courses, only 684 received at least one notice about the Literature Review library guide, and only 226 students received both scheduled notices. The overall response across courses and including students enrolled in courses where at least one notice was posted was only was $3.5 \%(n=24)$. Response varied by course, with the highest response from students enrolled in the early undergraduate course (14\%) and the lowest 
rate of response coming from students enrolled in the undergraduate later course $(n=1)$. A more thorough examination of response patterns did show that in courses where the faculty member did post two announcements, there was a higher response rate (Table 1).

\begin{tabular}{|c|c|c|c|c|c|c|c|}
\hline $\begin{array}{c}\text { Cour } \\
\text { ses }\end{array}$ & $\begin{array}{c}\text { Final } \\
\text { Roster }\end{array}$ & $\begin{array}{c}\# \\
\text { Students } \\
\text { Either } \\
\text { Notice }\end{array}$ & $\begin{array}{c}\# \\
\text { Students } \\
\text { Both } \\
\text { Notices }\end{array}$ & $\begin{array}{c}\text { \% Students } \\
\text { Receiving } \\
\text { Both } \\
\text { Notices }\end{array}$ & $\begin{array}{c}\text { Total \# } \\
\text { Response }\end{array}$ & $\begin{array}{c}\text { Total \% } \\
\text { Response }\end{array}$ & $\begin{array}{c}\text { Total \% } \\
\text { Response } \\
\text { Students } \\
\text { Receiving } \\
\text { Both }\end{array}$ \\
\hline$U-E$ & 83 & 70 & 39 & $47 \%$ & 12 & $14 \%$ & $31 \%$ \\
\hline$G-E$ & 232 & 133 & 47 & $20 \%$ & 6 & $3 \%$ & $13 \%$ \\
\hline $\mathrm{U}-\mathrm{L}$ & 561 & 295 & 89 & $16 \%$ & 1 & $0 \%$ & $1 \%$ \\
\hline $\mathrm{G}-\mathrm{L}$ & 314 & 186 & 51 & $16 \%$ & 5 & $2 \%$ & $10 \%$ \\
\hline
\end{tabular}

Table 1. Recruitment and Response Patterns. "U" is the "undergraduate" courses and "G" is the "graduate" courses. "E" is the "early" courses and " $L$ " is the "late" courses.

Since access to the Literature Review library guide resource was only made available through the faculty announcements, it was not surprising to see that data from the library guide's analytics also showed somewhat higher resource views when the faculty shared the information with their students (see Figure 1). It also appeared that page hits were higher after the first notice than after the second notice. The early increased number of resource page hits might have also been related to faculty accessing the resource themselves before posting the information in their classes. It was impossible to connect page hits to individual students, faculty or identified courses in this study.

\section{Method of Data Analysis}

Initially, descriptive statistics were run on all items. Limited response and small group sample sizes (see Table 1) precluded hypothesis testing and as a result, the findings presented focuses on response frequencies when examining group differences. 


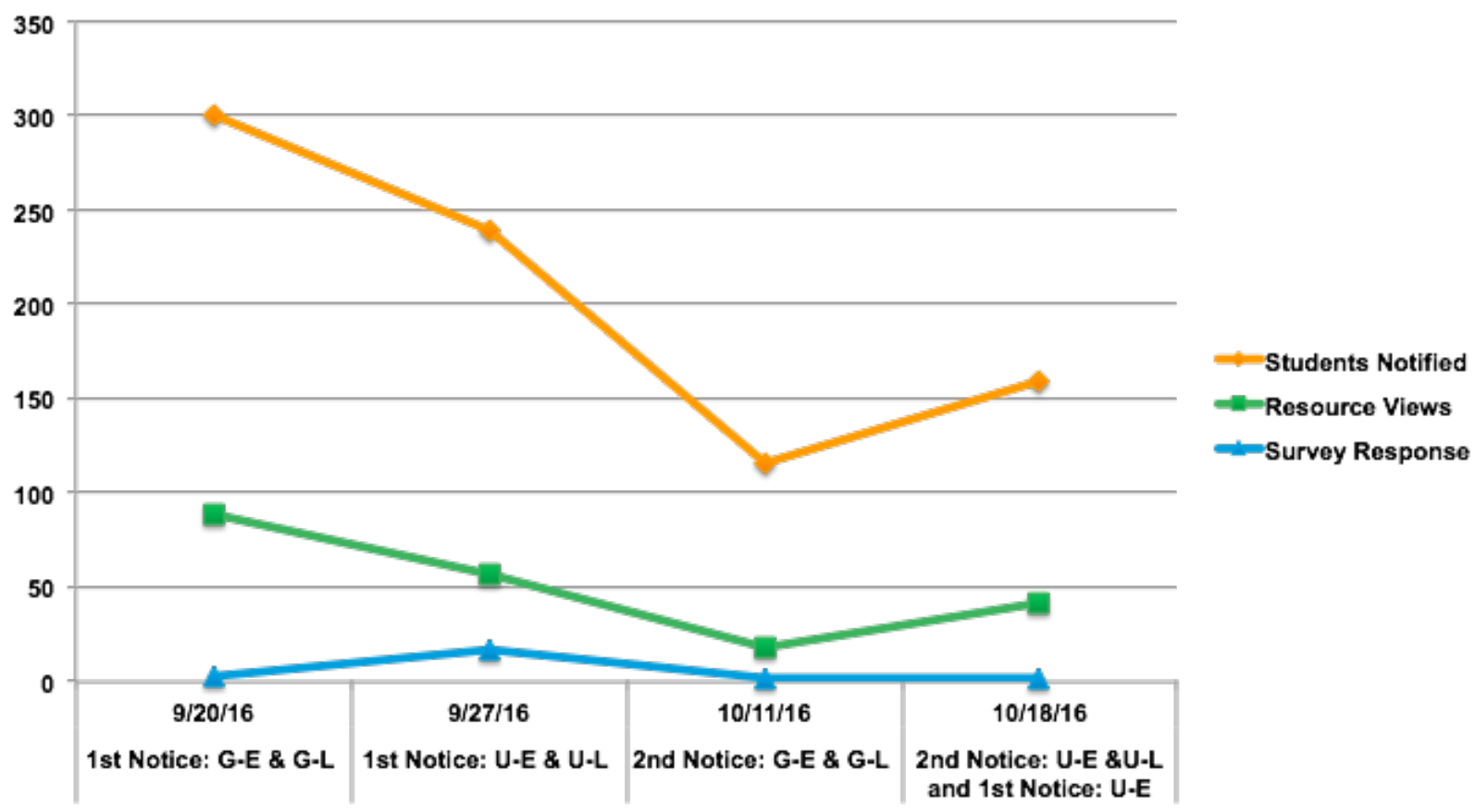

Figure 1. Resource Views and Survey Response

\section{Results}

Although the study was designed to examine mean differences between groups (undergraduate students versus graduate students and students enrolled in courses early in the program versus student enrolled in later courses), the low response rate resulted in no statistical significance between groups. Findings were examined for descriptive purposes and the trends, though not statistically significant, were used to revise the resource and to inform future development of University Library guides.

\section{Satisfaction with Resource}

Across undergraduate and graduate business research courses, and across courses that were taken early in the programs and courses that were taken later in the programs, students indicated they were very satisfied with the Literature Review library guide $(\bar{X}=4.08)$ and that they would very likely use the Literature Review library guide again $(\bar{X}=4.04)$.

There were almost no differences in how undergraduate and graduate students rated how likely they were to use the Literature Review library guide again (undergraduate $\bar{X}=4.08$, graduate $\bar{X}=4.00$ ) or how satisfied they were with their experience with the Literature Review library guide (undergraduate $\bar{X}=4.15$, graduate $\bar{X}=4.00$ ).

\section{Perception of Usability}

Similarly, students across levels and courses indicated they were satisfied with the way the Literature Review library guide performed $(\bar{X}=4.22)$, the look and feel of the guide $(\bar{X}=4.09)$, navigation $(\bar{X}=4.00)$ and the design intuitiveness $(\bar{X}=3.96)$. Students across levels and courses also tended to agree that the Literature Review library guide was easy to use $(\bar{X}=3.78)$, that they 
imagined most people would learn to use the guide very quickly $(\bar{X}=3.65)$, and that they found the various elements of the guide well integrated $(\bar{X}=3.58)$.

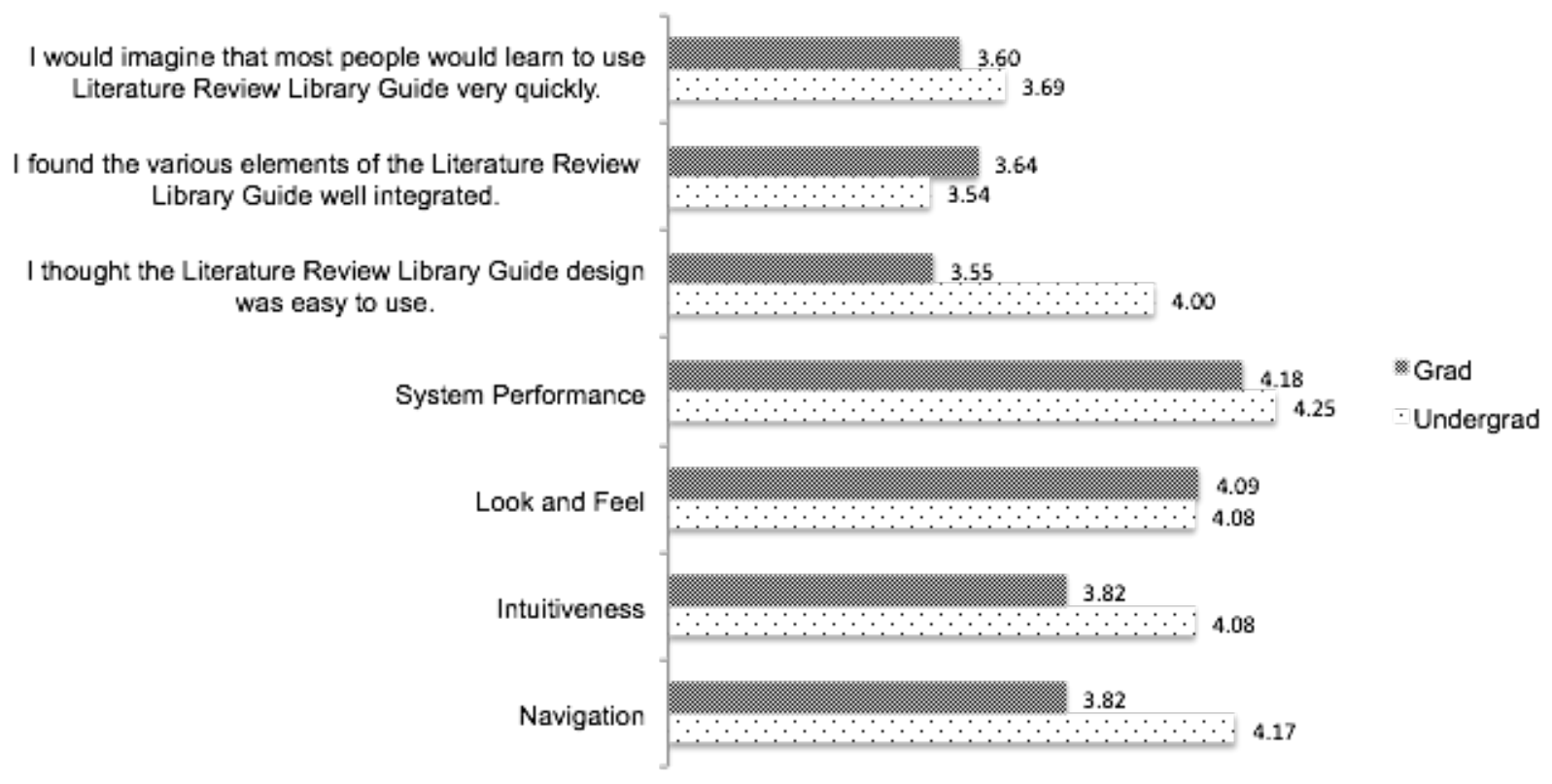

Figure 2. Usability Items - Undergraduate vs. Graduate Students (means reported)

Examining patterns in perceived usability across the undergraduate and graduate business students suggest minimal differences except with regards to the question about how easy the Literature Review library guide was to use, where the undergraduates were more likely to agree $(\bar{X}=4.00)$ as compared to the graduate students $(\bar{X}=3.55)$. Similar patterns were found around the questions about perceived intuitiveness (undergraduate $\bar{X}=4.08$, graduate $\bar{X}=3.82$ ) and about the design and navigation (undergraduate $\bar{X}=4.17$, graduate $\bar{X}=3.82$ ) of the resource.

When asked about what students found most valuable about the Literature Review library guide, undergraduate students reported, "The layout of the site was very easy to read and navigate" and "Everything is pretty easy. No complaints so far." Some graduate students reported similar comments, such as explaining what they felt was most valuable was "The ease of information" and "The ease of use... because it means it will be user-friendly and more people will be able to use it as well." However, one graduate student explained when asked what could be improved about the site, "A direct link would be most efficient. The way I was taught to access the resource was like a treasure map." And another graduate student explained, "I would like more information explaining what each of the databases is and what it is best used for."

\section{Value of Content}

Students across levels and courses also reported they would likely use the Literature Review library guide often $(\bar{X}=3.83)$. When asked whether they would use the various resources within the Literature Review library guide, students tended to agree that they would likely often use the Managing References $(\bar{X}=4.24)$, the Writing Resources $(\bar{X}=4.19)$, the Evaluate Sources $(\bar{X}=4.00)$, the Develop a Search Strategy $(\bar{X}=4.00)$ and the Start Writing $(\bar{X}=3.95)$ resources. 
Although all students tended to indicate they found the resources in the Literature Review library guide important by explaining that they would likely use the features often, when examining differences between undergraduate and graduate students on their perceptions of the specific resources included in the Literature Review library guide, graduate students appeared to value a few of the writing and reference resources more highly than their undergraduate peers. For example, graduate students were more likely to report that they would often use the Writing Resources (graduate $\bar{X}=4.56$, undergraduate $\bar{X}=3.92$ ) and the Managing References (graduate $\bar{X}=4.50$, undergraduate $\bar{X}=4.00$ ) (Figure 3 ).

I would use the Literature Review Library Guide often.
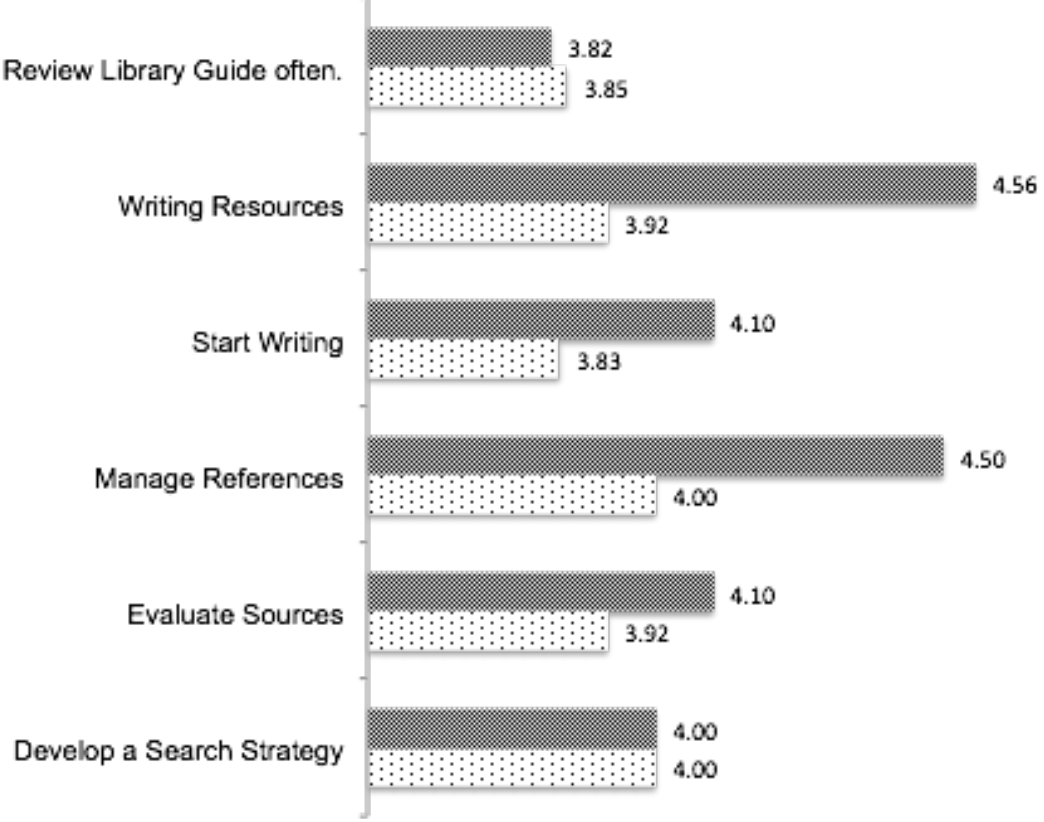

粼 Grad

: Undergrad

Figure 3. Content Items - Undergraduate vs. Graduate Students (means reported)

Undergraduate students indicated that specific features from the University Writing Center, which was available from the Literature Review library guide, were helpful. For example, one student said, "...I think the center of writing excellence has helped me out the most". Another undergraduate said, "I like to have access to the APA template," and another suggested, "The resource management is the most valuable to me it helps you cite resources... Awesome!". In contrast, the graduate students focused on elements related to searching the literature. For example, one graduate student reported that they found the most valuable feature to be to "Evaluate sources, it allowed me to find credible sources." Another graduate student explained: "The most valuable element was Develop a Search Strategy. Assignments can have thousands of articles, books, etc. to reference. If you educated on how to narrow and redefine your search, you increase your chances of locating relevant data."

\section{Timing and Literature Review Library Guide}

This study was designed to examine whether the timing of introduction of the Literature Review library guide into the academic programs was related to students' reported use of the guide and their satisfaction with the guide. Timing was considered in relation to courses (early in the 
program and later in the program) as well as to programs (undergraduate business and graduate business).

When looking at response patterns related to the timing of the introduction of the Literature Review library guide, those students enrolled in courses earlier in their program were much more likely to indicate they would use the resource again (early $\bar{X}=4.17$, late $\bar{X}=3.67$ ) and that they were satisfied with their experience (early $\bar{X}=4.17$, late $\bar{X}=3.83$ ). Because the response set was so small and because there was only one undergraduate response from the later course, it should be noted that the "late" respondents were nearly all graduate students. The conflation of graduate student level with the "later" course response should be considered when looking at the comparison of early students and late students on the specific usability and content items in this study.

All students were asked how likely it was that they would use the Literature Review library guide had it been introduced at a different point in their degree program. Students enrolled in the earlier courses indicated that they were less likely $(\bar{X}=3.61)$ to use the resource more had it been introduced later in the course. In contrast, the students enrolled in the later courses indicated they were highly likely $(\bar{X}=4.50)$ to use the resource more had it been introduced earlier in their program. The timing of the introduction of the Literature Review library guide within academic programs may be related to whether or not students use the resource. In particular, the response patterns suggest that students would like to be introduced to this resource earlier in their academic programs. One graduate student enrolled in the later research course explained:

This does not answer your question, but I wanted to provide additional feedback. I would suggest this guide is required resource students should review. I am currently in my last course and have sent questions to the librarians and found their responses very helpful. If I were aware of this resource, I would have taken time to utilize it and apply suggestions it provides.

\section{Guide Design}

\section{Discussion}

While both undergraduate and graduate students expressed satisfaction with the guide and indicated that they would use it again, the study has identified the need to revise the guide based on students' perceptions of usability. The fact that ease of use, ability to quickly learn how to use the guide and integration of elements were all rated slightly lower than other variables of the guide point to areas for improvement. Further development of the Literature Review library guide will be completed with additional usability testing to ensure that the guide meets students' preferences for information literacy framework with a clean design, consistent and meaningful language, and a limited number of links and pages on those guides (Ouellette, 2001). While keeping these preferences in mind, ensuring that the guides have the appropriate content that meets the curriculum outcomes for information literacy instruction will need to be assessed. Finding the balance between providing enough information and avoiding the tendency to overwhelm students with too much information will require additional student feedback, curriculum design, and mapping of curriculum outcomes. A good method to support this might be to follow Ouellette's (2001) recommendation to break guides down into sub-disciplines. While the Literature Review library guide is not associated with a particular discipline, and it is focused specifically on resources for completing a literature review, the guide could be further streamlined and broken down into "bite-sized" guides and embedded at students' point of need. 
Only minimal differences between undergraduate and graduate business students' perceptions of usability of the guide were found. However, graduate students reported ease of use and intuitiveness and navigation slightly lower than undergraduates, and this pattern may be due to different expectations on the part of the two student groups as well as different academic needs. Future research could explore this area further. Also, a future approach to addressing unique undergraduate and graduate student needs may involve building two separate Literature Review library guides, one for an undergraduate audience and the other for a graduate audience. Using a service design approach to guide development will help identify if separate guides are a better option, help create guides that are more supportive of differing student needs, and better contribute to the success of these two groups of students (German, 2017).

Developing a better understanding of the base knowledge, needs, and expectations of different groups of students will help with future guide design. Students place a high value on electronic resources and are often confused by the language that librarians use (Ouellette 2001, $\mathrm{Wu} \&$ Chen, 2012). Given that students may not understand what resources are available in their library, or how to navigate to those resources, guides should be designed with the goal of supporting student needs. For example, libraries should aim to make electronic resources easily noticeable, make them easy to find, and clearly describe resource content. Knowing that students are more likely to use a resource that is recommended by faculty, and that they are more likely to report greater success and satisfaction when faculty or a librarian recommended that resource specifically for an assignment, will inform future guide development as well as placement of the guide (Ouellette, $2001 \&$ Spahr, 2015).

\section{Content Relevance}

Comparing undergraduate and graduate business students' responses around the value of content also suggests a potential need to model this guide differently for undergraduate and graduate students. Graduate students were more likely to report that they would use the Writing Resources and Managing References pages often than undergraduates. Undergraduate students indicated in the open-ended question that the content of the University Writing Center page was helpful. A possible reason for this is the undergraduate students are still learning the process of writing, while graduate students conceivably need less help in this area. In contrast, the graduate students focus on the elements related to searching the literature such as content on how to evaluate sources and how to develop a search strategy.

\section{Timing of Guide Introduction}

The fact that students who were introduced to the guide in courses later in their program reported that they were highly likely to have used the guide had it been introduced earlier in their program was unsurprising and supports the results indicating the students found the guide valuable. It is also not surprising that students who were introduced to the guide early in their program were less likely to report that they would use the guide more had it been introduced at a later time. The students recognized that this guide provided more value at certain times in their program and that they would have had a greater need for the guide earlier in their program. Rempel (2010), Neves and Dooley (2011), Mahaffey (2012), and Shank and Dewald (2010) identified that the earlier information literacy instruction is introduced and more often the students are exposed to information literacy concepts, the higher the probability the students will apply the skills in their coursework. The library guides need to be embedded at the appropriate time. "The closer the link 
between course assignments and library resources to help with those assignments, the greater likelihood that students will access library information” (Shank \& Dewald, 2003, p. 41).

One way to help determine if a guide is embedded at the correct point when students need the information is to look at the use analytics. The LibGuides platform provides data on the number of views at the guide, page, and link or asset level. It would be valuable to know the number of unique user views, repeat visitors, and session length to gain a more comprehensive understanding of use. Google Analytics is one tool that can provide this data and this tool will be integrated for future evaluation of guide use. If the number of unique visitors increases shortly after a guide is introduced in the curriculum, this can indicate that the guide is findable. Looking at data for repeat visitors can help determine if the content of the guide is valuable and meeting student learning outcomes.

\section{Future Research}

Future research on course specific guides will be conducted with continued evaluation of student perceptions of usability, the value of the content, and timing of guide introduction while additionally evaluating usage. These guides will be built for doctoral studies supporting research methods, supporting doctoral writing, and publication processes for their doctoral work. This study will include additional data collection points such as student end of course surveys, faculty end of course surveys, and student data (grades, continued course enrollment, and GPA). By engaging the faculty in the process, we are looking at having more student use of the project.

Students noted that they would have used the guides more if they were introduced earlier within their program. Future work needs to include identification of library resource needs, identification of when in a program the resource is introduced, and where the resource is embedded within the structure of the course.

After the completion of this initial study, the University Library has begun building library guides that are embedded in the first six courses that are taken by all undergraduate students. The guides are being built to support signature assessment assignments in a series of courses developed to promote student success. These guides fit the definition of Micro-Level Library Courseware Involvement (MiLLCI) as described by Shenk and Dewald (2003). MiLLCI can be advantageous by allowing student access to focused library content at the point of need within the LMS. Embedding the guides directly into the curriculum should increase use of the guides and the associated library resources.

Library resource design can benefit from ongoing, gradual user experience testing (Pennington, 2015; Sonsteby \& DeJonghe, 2013; Tidal, 2012). Usability design can help librarians develop awareness of the problems that their students encounter and help them build library resources more focused on their students' needs (Pennington, 2015; Sonsteby \& DeJonghe, 2013; Tidal, 2012). These findings suggest that additional user testing of the library guides should be completed. As changes are made to the design of the library pages, it is advantageous to make sure that the students are still able to follow steps to find resources on the library guide page with minimal disruption. Future research will involve completing usability tests with small groups of students who will be impacted by the design changes and then ask these students to show their steps, and the researchers will observe what they do. By conducting this research with students with different demographics, additional customization of the library guide to meet individual student needs. 


\section{References}

Beagle, D. (2000). Web-based learning environments: Do libraries matter? College \& Research Libraries, 61(4), 367-379. doi: 10.5860/crl.61.4.367

Bellard, E. M. (2005). Information literacy needs of nontraditional graduate students in social work. Research Strategies, 20(4), 494-505. doi: 10.1016/j.resstr.2006.12.019

Bowen, A. (2012). A LibGuides presence in a Blackboard environment. Reference Services Review, 40(3), 449-468. doi: 10.1108/00907321211254698

Buehler, M. A. (2004). Where is the library in course management software? Journal of Library Administration, 41(1), 75-84. doi: 10.1300/J111v41n01_07

Catalano, A. J., \& Phillips, S. R. (2016). Information literacy and retention: A case study of the value of the library. Evidence Based Library and Information Practice, 11(4). doi: 10.18438/B82K $7 \mathrm{~W}$

Cothran, T. (2011). Google scholar acceptance and use among graduate students: A quantitative study. Library \& Information Science Research, 33(4), 283-301. doi: 10.1016/j.lisr.2011.02.001

German, E. (2017). LibGuides for instruction: A service design point of view from an academic library. Reference \& User Services Quarterly, 56(3), 162-167. doi: $10.5860 /$ rusq.56n3.162

Gilbert, J. K., Knutson, K., \& Gilbert, C. P. (2012). Adding an integrated library component to an undergraduate research methods course. PS: Political Science and Politics, 45(1), 112118. doi: $10.1017 / \mathrm{S} 1049096511001788$

Green, R., \& Bowser, M. (2002). Managing thesis anxiety: A faculty-librarian partnership to guide off-campus graduate education students through the thesis process. Journal of Library Administration, 37(3), 341-354. doi:10.1300/J111v37n03_04

Haddow, G. (2013). Academic library use and student retention: A quantitative analysis. Library \& Information Science Research, 35(2), 127-136. doi: 10.1016/j.lisr.2012.12.002

Khan, A., \& Qutab, S. (2016). Understanding research students' behavioural intention in the adoption of digital libraries: A Pakistani perspective. Library Review, 65(4/5), 295-319. doi: 10.1108/LR-06-2015-0070

Lombardo, S. V., Miree, C. E. (2003). Caught in the web: The impact of library instruction on business students' perceptions and use of print and online resources. College \& Research Libraries, 64, 6-22. doi: 10.5860/crl.64.1.6 
Liu, Z. (2006). Print vs. electronic resources: A study of user perceptions, preferences, and use. Information Processing \& Management, 42, 583-592. doi: 10.1016/j.ipm.2004.12.002

Liu, Z., \& Luo, L. (2011). A comparative study of digital library use: Factors, perceived influences, and satisfaction. The Journal of Academic Librarianship, 37(3), 230-236. doi: 10.1016/j.acalib.2011.02.015

Mahaffy, M. (2012). Student use of library research guides following library instruction. Communications in Information Literacy, 6(2), 202-213. Retreived from: http://www.comminfolit.org/index.php?journal=cil\&page=article\&op=view\&path $\rceil=v 6 i 2$ p202

May, D. \& Leighton, H. V. (2013). Using a library-based course page to improve research skills in an undergraduate international business law course. Journal of Legal Studies Education, 30(2), 295-319. doi: 10.1111/jlse.12003

Murray, A. (2015). Academic libraries and high-impact practices for student retention: Library deans' perspectives. Portal: Libraries and the Academy, 15(3), 471-487. Retrieved from: http://digitalcommons.wku.edu/diss/57

National Center for Education Statistics. (2015, Fall). IPEDS : Integrated Postsecondary Education Data System : University of Phoenix: Enrollment. Washington, D.C.: National Center for Education Statistics. Retrieved from: https://nces.ed.gov/collegenavigator/?q=university + of + phoenix \&s=all\&id $=484613 \#$ enrol $\underline{\mathrm{mt}}$

Neves, K., \& Dooley, S. J. (2011). Using LibGuides to offer library service to undergraduate medical students based on the case-oriented problem solving curriculum model. Journal of the Medical Library Association, 99(1), 94-7. doi: 10.3163/1536-5050.99.1.017

Oullette, D. (2001). Subject guides in academic libraries: A user-centered study of uses and perceptions. The Canadian Journal of Information and Library Sciences, 36(4), 436-451. doi: $10.1353 /$ ils.2011.0024

Pennington, B. (2015). ERM UX: Electronic Resources Management and the User Experience. Serials Review, 41(3), 194-198. doi: 10.1080/00987913.2015.1069527

Rempel, H. G. (2010). A longitudinal assessment of graduate student research behavior and the impact of attending a library literature review workshop. College \& Research Libraries, 71(6), 532-547. doi: 10.5860/crl-79

Shank, J. D., \& Dewald, N. H. (2003). Establishing our presence in courseware: Adding library services to the virtual classroom. Information Technology and Libraries, 22(1), 38-43. 
Sonsteby, A. \& DeJonghe, J. (2013). Usability testing, user-centered design, and LibGuides subject guides: A case study. Journal of Web Librarianship, 7(1), 83-94. doi:

10.1080/19322909.2013.747366

Spahr, K. (2015). Influences on undergraduate business students' perceptions about the adequacy of library information resources. Behavioral \& Social Sciences Librarian, 34(4), $214-$ 229. doi: 10.1080/01639269.2015.1096183

Tidal, J. (2012). Creating a user-centered library homepage: A case study. OCLC Systems and Services, 28(2), 90-100. doi: 10.1108/10650751211236631

Vygotsky, Lev (1978). Mind in society. London: Harvard University Press

Wakeham, M., Roberts, A., Shelley, J. \& Wells, P. (2012). Library subject guides: A case study of evidence-informed library development. Journal of

Librarianship and Information Science, 44(3), 199-207. doi: 10.1177/0961000611434757

Wu, M. \& Chen, S. (2012). How graduate students perceive, use, and manage electronic resources. Aslib Proceedings, 64(6), 641-652. doi: 10.1108/00012531211281779 